Vol 2, No 3, Oktober 2021, pp. 82-86

ISSN 2721-0715 (media online)

DOI 10.47065/jharma.v2i3.1302

\title{
Formulasi Sediaan Lip Gloss Dari Esktrak Etanol Ubi Jalar Ungu (Ipomoea Batatas L)
}

\author{
Novia Agustia, Rosa Mardiana* \\ Akademi Farmasi YPPM Mandiri, Banda Aceh, Indonesia \\ Emal: rosa29mardiana@gmail.com
}

\begin{abstract}
Abstrak-Indonesia merupakan negara kaya akan tanaman alam yang bisa dimanfaatkan sebagai zat warna untuk kosmetik salah satunya ubi jalar ungu (Ipomoea batatas L.). Ubi jalar ungu (Ipomoea batatas L.) ini tumbuh di daerah tropis dan 1.9 juta ton produktivitas per tahun. Ubi jalar ungu (Ipomoea batatas L.) merupakan zat pewarna alami dan lebih aman dibanding dengan pewarna sintesis. Menurut (Dian, 2017), Ubi jalar ungu (Ipomoea batatas L.) mengandung zat pewarna antosianin yang berperan dalam menghambat aktivitas enzim amulase dan dapat berfungsi sebagai antioksidan. Antioksidan mempunyai fungsi untuk melembabkan bibir dan mengangkat sel kulit mati selain itu antioksidan juga diperlukan tubuh untuk menetralisir radikal bebas. Lip gloss yaitu jenis sediaan pewarna bibir yang mengandung minyak yang tinggi sehingga memberikan kesan melembabkan, berkilau atau gloss. Penelitian ini menggunakan ekstrak ubi jalar ungu (Ipomoea batatas L) sebagai pewarna alami. Penelitian ini bertujuan untuk menformulasikan ekstrak ubi jalar ungu dalam bentuk sediaan lip gloss dan untuk melihat bagaimana stabilitas lip gloss yang baik. Ekstrak ubi jalar ungu (Ipomoea batatas L) dibuat dengan cara maserasi menggunakan pelarut etanol 96\% sampai memperoleh ekstrak cair dan kemudian dipekatkan menggunakan vacum rotary evaporator hingga diperoleh ekstrak kental. Formulasi sediaan lip gloss terdiri dari cera alba, paraffin cair, vaselin album, emulsifying wax, BHT (Butyl Hidroksi Toluen) nipagin, gliserin, oleum ricini serta penambahan pewarna ekstrak ubi jalar ungu. Konsentrasi yang digunakan dalam lip gloss adalah 0\% (F0), 20\% (F1), dan 35\% (F2). Evaluasi sediaan lip gloss meliputi uji organoleptis, homogenitas, daya oles, uji pH, kesukaan dan uji iritasi. Hasil evaluasi sediaan menunjukkan bahwa sediaan homogen, dan memenuhi persyaratan yang baik. Hasil uji daya oles menunjukkan bahwa konsentrasi 0\% (F0), 20\% (F1), dan $35 \%$ (F2) adalah melekat. Hasil uji kesukaan menunjukkan bahwa pada konsentrasi 35\% (F2) yang paling banyak disukai oleh panelis. Sehingga dapat disimpulkan bahwa sediaan yang paling baik terdapat pada konsentrasi 35\% (F2).
\end{abstract}

Kata Kunci: Ubi Jalar Ungu (Ipomoea Batatas L); Uji Iritasi; Lip Gloss

Abstract-Indonesia is a country rich in natural plants that can be used as dyes for cosmetics, one of which is purple sweet potato (Ipomoea batatas L.). This purple sweet potato (Ipomoea batatas L.) grows in the tropics and produces 1.9 million tons of productivity per year. Purple sweet potato (Ipomoea batatas L.) is a natural dye and is safer than synthetic dyes. According to (Dian, 2017), purple sweet potato (Ipomoea batatas L.) contains anthocyanin dyes which play a role in inhibiting the activity of the amulase enzyme and can function as antioxidants. Antioxidants have a function to moisturize the lips and remove dead skin cells, besides that antioxidants are also needed by the body to neutralize free radicals. Lip gloss is a type of lip color preparation that contains high oil so that it gives a moisturizing, shiny or gloss impression. This study used purple sweet potato (Ipomoea batatas L) extract as a natural dye. This study aims to formulate purple sweet potato extract in the form of lip gloss and to see how good the stability of lip gloss is. Purple sweet potato (Ipomoea batatas L) extract was prepared by maceration using $96 \%$ ethanol solvent to obtain a liquid extract and then concentrated using a vacuum rotary evaporator to obtain a thick extract. The lip gloss formulation consisted of cera alba, liquid paraffin, vaseline album, emulsifying wax, BHT (Butyl Hydroxy Toluene) nipagin, glycerin, oleum ricini and the addition of purple sweet potato extract coloring. Concentrations used in lip gloss are 0\% (F0), 20\% (F1), and 35\% (F2). Evaluation of lip gloss preparations included organoleptic test, homogeneity, smearing power, $\mathrm{pH}$ test, preference and irritation test. The results of the evaluation of the preparations showed that the preparations were homogeneous, and met the requirements well. The results of the smear test showed that the concentrations of $0 \%(\mathrm{~F} 0), 20 \%(\mathrm{~F} 1)$, and 35\% (F2) were attached. The results of the preference test showed that at a concentration of $35 \%$ (F2) the panelists preferred the most. So it can be concluded that the best preparation is found at a concentration of 35\% (F2).

Keywords: Purple Sweet Potato (Ipomoea Batatas L); Irritation Test; Lip Gloss

\section{PENDAHULUAN}

Ubi jalar ungu (Ipomoea batatas L.) merupakan salah satu jenis ubi jalar yang banyak ditemui di Indonesia selain berwarna putih, kuning dan merah. Ubi jalar ungu (Ipomoea batatas L.) memiliki ungu yang cukup pekat pada daging ubinya sehingga banyak menarik perhatian. Ubi jalar ungu (Ipomoea batatas L) juga mengandung pigmen antosianin yang lebih tinggi daripada ubi jalar jenis lain. Pigmennya lebih stabil bila dibandingkan antosianin dari sumber lain seperti kubis merah, dan jagung merah. Ubi jalar ungu (Ipomoea batatas L.) mulai dikenal menyebar ke seluruh dunia terutama negara-negara yang beriklim tropis.

Ubi jalar ungu (Ipomoea batatas L.) merupakan zat pewarna alami dan lebih aman dibanding dengan pewarna sintesis. Menurut (Dian, 2017), Ubi jalar ungu (Ipomoea batatas L.) mengandung zat pewarna antosianin yang berperan dalam menghambat aktivitas enzim amulase dan dapat berfungsi sebagai antioksidan.

Kosmetik memiliki sejarah panjang dalam kehidupan manusia. Berdasarkan hasil penggalian arkeologi, diketahui bahwa kosmetik telah digunakan oleh manusia yang hidup pada zaman dahulu. Saat ini, kosmetik menjadi bagian penting dalam kehidupan sehari-hari, jumlah kosmetik yang digunakan terus meningkat seiring dengan pertambahan jumlah penduduk setiap tahun (Risnawati, 2012).

Menurut Dian (2017) komponen lip gloss terdiri dari pigmen, minyak lilin, dan pelembut yang memberikan warna, tekstur, dan pelindung terhadap bibir. Pigmen yang digunakan pada formulasi lip gloss masih banyak yang berasal dari bahan sintetik. Untuk mempertimbangkan efek samping yang ditimbulkan pigmen sintesis maka pada penelitian ini akan dikembangkan dengan menggunakan pigmen alami yang relatif aman. 


\section{Journal of Pharmaceutical and Health Research}

Vol 2, No 3, Oktober 2021, pp. 82-86

ISSN 2721-0715 (media online)

DOI 10.47065/jharma.v2i3.1302

Bibir merupakan kulit yang memiliki ciri tersendiri dengan kulit yang sangat tipis, aliran darah lebih banyak mengaliri di daerah permukaan kulit bibir, tidak terdapat kelenjer keringat, dan sangat jarang terdapat kelenjer lemak sehingga kulit bibir lebih peka dibandingkan kulit lainnya. Karena itu hendaknya berhati-hati dalam memilih bahan yang digunakan untuk sediaan lipstik, terutama dalam hal memilih zat warna yang digunakan untuk maksud pembuatan sediaan tersebut (Risnawati, 2012).

Menurut Yogaswara (2015), ketersediaan ubi jalar dengan warna ungu yang melimpah di Indonesia menyebabkan umbi ini berpotensi untuk dikembangkan sebagai zat warna pada sediaan kosmetik. Di dalam membuat sediaan lip gloss yang baik tidak hanya zat pewarna saja yang perlu diperhatikan. Bentuk fisik dari sediaan juga memegang peranan penting untuk menarik konsumen. Komponen yang sangat mempengaruhi bentuk dan stabilitas fisik lip gloss.

\section{METODOLOGI PENELITIAN}

Penelitian ini merupakan penelitian yang bersifat eksperimental yang dilaksanakan di laboratorium untuk membuat formulasi sediaan lip gloss dari ekstrak etanol ubi jalar ungu (Ipomoea batatas L.).

\subsection{Prosedur Pembuatan Sediaan Lip Gloss}

Ditimbang bahan-bahan yang akan digunakan, dimasukkan vaselin album dan cera alba dilumerkan diatas cawan penguap aduk hingga homogen (massa A), masukkan BHT dilarutkan dengan sedikit minyak jarak, aduk hingga homogen (massa B), dimasukkan emulsifying wax dilumerkan diatas cawan penguap, tambahkan massa B aduk hingga homogen (massa C), kemudian campurkan massa A dan massa C diaduk perlahan-lahan, tambahkan nipagin aduk hingga homogen, tambahkan gliserin dan paraffin liquid aduk hingga homogen, kemudian tambahkan minyak jarak aduk hingga homogen, kemudian masukkan kedalam tempat lip gloss.

Tabel 1. Formulasi Sediaan (Euis dan Ine, 2018)

\begin{tabular}{llccc}
\hline No & \multicolumn{1}{c}{ Bahan } & $\begin{array}{c}\text { F0 } \\
(\%)\end{array}$ & $\begin{array}{c}\text { F1 } \\
(\%)\end{array}$ & $\begin{array}{c}\text { F2 } \\
(\%)\end{array}$ \\
\hline 1 & Esktrak ubi jalar ungu & - & 20 & 35 \\
2 & Cera alba & 3 & 3 & 3 \\
3 & Paraffin liquid & 10 & 10 & 10 \\
4 & Vaselin album & 13 & 13 & 13 \\
5 & Emulsifying wax & 30 & 30 & 30 \\
6 & BHT & 0,5 & 0,5 & 0,5 \\
7 & Nipagin & 0,5 & 0,5 & 0,5 \\
8 & Gliserin & 3 & 3 & 3 \\
9 & Oleum ricini ad & 100 & 100 & 100 \\
\hline
\end{tabular}

Sumber: Euis dan Ine, 2018

Keterangan:

1. F0 : Formulasi Basis Tanpa Ekstrak.

2. F1 : Formulasi Sediaan Lip Gloss dari Esktrak Etanol Ubi Jalar Ungu (Ipomoea batatas L) $20 \mathrm{~g}$.

3. F2 : Formulasi Sediaan Lip Gloss dari Esktrak Etanol Ubi Jalar Ungu (Ipomoea batatas L) $35 \mathrm{~g}$.

\section{HASIL DAN PEMBAHASAN}

\subsection{Esktrak Ubi Jalar Ungu}

Ubi jalar ungu (Ipomoea batatas L) di esktrak dengan menggunakan pelarut etanol menggunakan prinsip esktrak maserasi dengan perbandingan 1:10. Hasil esktrak simplisia ubi jalar ungu dengan proses maserasi sebanyak $400 \mathrm{~g}$ simplisia ubi jalar ungu dengan pelarut etanol sebanyak $4 \mathrm{~L}$ yang dilakukan selama 7 hari memperolah hasil esktrak cair $3750 \mathrm{~L}$ setelah dipekatkan dengan menggunakan vacum rotary evaporator, maka diperoleh esktrak kental sebanyak $108 \mathrm{ml}$.

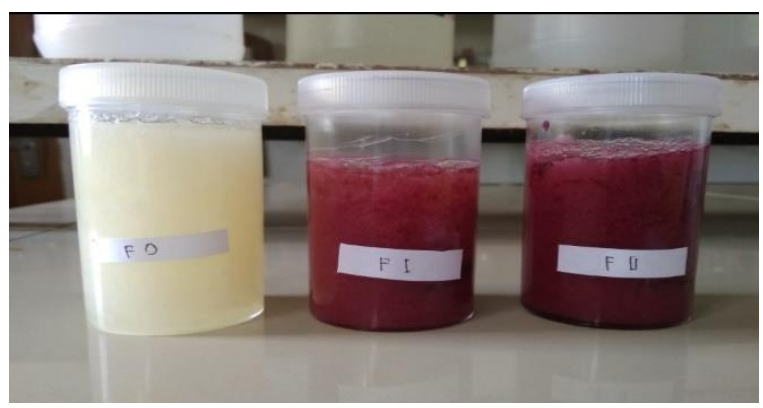

Gambar 1. Hasil Pembuatan Sediaan Lip Gloss 


\section{Journal of Pharmaceutical and Health Research}

Vol 2, No 3, Oktober 2021, pp. 82-86

ISSN 2721-0715 (media online)

DOI 10.47065/jharma.v2i3.1302

Keterangan :

F0 : Basis lip gloss

F1 : Lip gloss dengan konsentrasi $20 \%$

F2 : Lip gloss dengan konsentrasi $35 \%$

\subsection{Skrining Fitokimia}

Skrining fitikimia dilakukan untuk mengetahui kandungan senyawa metebolit sekunder apa saja yang terdapat dalam ubi jalar ungu. Data hasil skrining fitokimia yang telah diuji dapat dilihat pada tabel 2 berikut ini:

Tabel 2. Hasil Skrining Fitokimia

\begin{tabular}{lllc}
\hline \multicolumn{1}{c}{ Uji } & \multicolumn{1}{c}{ Reagen/Pereaksi } & \multicolumn{1}{c}{ Hasil } & Ket \\
\hline \multirow{2}{*}{ Alkaloid } & Pereaksi Dragendorf & Terbentuk endapan coklat jingga & + \\
& Pereaksi Bourchardat & Terbentuk merah kecoklatan & + \\
& Pereaksi Wagner & Terbentuk warna kemerahan & + \\
Saponin & Uji fotrh & Terbentuk gelombang & + \\
Tanin & FeCL 1\% & Tidak terbentuk larutan putih keruh & - \\
Polifenol & FeCL 1\% & Terbentuk larutan biru & + \\
Kuinon & Natrium Hidroksida & Tidak terbentuk larutan merah & - \\
Flavonoid & Uji Wlstates Sianin & Terbentuk larutan merah & + \\
Steroid & Uji Liberman-Burchardat & Tidak terbentuk larutan hijau & - \\
Triterpenoid & Uji Liberman-Burchardat & Terbentuk larutan merah & + \\
\hline
\end{tabular}

Dari hasil uji pada tabel 2 skrining fitokimia menunjukkan bahwa ada beberapa senyawa yang positif terindikasi pada ekstrak ubi jalar ungu berdasarkan perubahan warna setelah diberikan reagen, beberapa senyawa tersebut adalah senyawa alkaloid, saponin, polifenol, flavonoid, dan triterpenoid, sedangkan senyawa tanin, kuinon, dan steroid menunjukkan hasil yang negatif.

\subsection{Evaluasi Sediaan Lip Gloss}

Hasil pengamatan terhadap evaluasi sediaan lip gloss ubi jalar ungu meliputi uji organoleptis, uji homogenitas, uji daya oles, uji kesukaan, uji iritasi dan uji pH sebagai berikut :

a. Hasil Uji Organoleptis

Data hasil uji organoleptis dapat dilihat pada tabel 3 berikut ini :

Tabel 3. Hasil Pengamatan Uji Organoleptis

\begin{tabular}{ccccc}
\hline Formulasi & Warna & Bentuk & Bau & Tekstur \\
\hline F0 & Putih & Semi padat & Bau khas vaselin album & Lembut \\
F1 & Ungu pudar & Semi padat & Bau khas ubi jalar ungu & Lembut \\
F2 & Ungu pudar & Semi padat & Bau khas ubi jalar ungu & Lembut \\
\hline
\end{tabular}

Keterangan :

F0 : Formula lip gloss sebagai basis

F1 :Formula lip gloss dengan konsentrasi ekstrak ubi jalar ungu (Ipomoea batatas L) $20 \mathrm{~g}$.

F2 :Formula lip gloss dengan konsentrasi ekstrak ubi jalar ungu (Ipomoea batatas L) $35 \mathrm{~g}$.

Berdasarkan pada tabel 3 diatas, diperoleh hasil uji organoleptis yaitu pada formula 0 (basis) memiliki warna putih terbentuk semi padat dengan tekstur lembut dan memiliki bau khas veselin album. Formula 1 memiliki warna ungu pudar berbentuk semi padat dengan tekstur sangat lembut dan memiliki bau khas ubi jalar ungu. Formula 2 memiliki warna ungu pudar berbentuk semi padat dengan tekstur sangat lembut dan memiliki bau khas ubi jalar ungu. Pada uji organoleptis ini dapat diketahui bahwa dengan penambahan ekstrak ubi jalar ungu menghasilkan warna ungu pada sediaan.

b. Hasil uji Homogenitas

Data hasil uji homogenitas dapat dilihat pada Tabel 4.3 berikut ini :

Tabel 4. Hasil Pengamatan Uji Homogenitas

\begin{tabular}{ccc}
\hline Formulasi & Pengamatan & Keterangan \\
\hline F0 & Tidak ada butiran kasar & homogen \\
F1 & Tidak ada butiran kasar & homogen \\
F2 & Tidak ada butiran kasar & homogen \\
\hline
\end{tabular}

Uji homogenitas berdasarkan tabel 4 menunjukkan bahwa F0 (basis), F1, dan F2 memiliki susunan yang homogen. Hal ini ditandai dengan tidak adanya partikel-partikel asing dan butiran kasar dalam sediaan, sehingga pada uji homogenitas sediaan lip gloss dapat dikatakan memenuhi syarat uji mutu fisik. 


\section{Journal of Pharmaceutical and Health Research}

Vol 2, No 3, Oktober 2021, pp. 82-86

ISSN 2721-0715 (media online)

DOI 10.47065/jharma.v2i3.1302

c. Uji Daya Oles dan Uji pH

Data hasil daya oles dan homogenitas dapat dilihat pada tabel 5 berikut ini :

Tabel 5. Hasil Uji Daya Oles dan Uji pH

\begin{tabular}{cccc}
\hline Uji & \multicolumn{3}{c}{ Formula } \\
& F0 & F1 & F2 \\
\hline Daya Oles & Melekat & Melekat & Melekat \\
pH & 5 & 4 & 4 \\
\hline
\end{tabular}

Pemeriksaan daya oles lip gloss menunjukkan bahwa sediaan mempunyai kemampuan daya oles yang bagus. Karena pada saat dioleskan pada punggung tangan dapat menempel pada punggung tangan. Hasil pengujian $\mathrm{pH}$ sediaan lip gloss menggunakan ekstrak ubi jalar ungu menunjukkan bahwa formula 0 (basis) memiliki pH 5, formula 1 memiliki $\mathrm{pH} 4$, dan formula 2 memiliki $\mathrm{pH} 4$. Formula 0 sampai 2 mempunyai syarat $\mathrm{pH}$ evalusi sediaan lip gloss, karena sediaan yang dihasilkan pHnya mendekati $\mathrm{pH}$ fisiologis kulit bibir yaitu 4,0-6,5.

d. Uji kesukaan

Data hasil uji kesukaan dapat dilihat pada tabel 6 berikut ini :

Tabel 6. Hasil Uji Kesukaan

\begin{tabular}{ccccc}
\hline Sampel & \multicolumn{4}{c}{ Hasil Pengamatan } \\
& SSS & SS & S & TS \\
\hline F0 & - & 3 & - & - \\
F1 & - & - & 3 & - \\
F2 & 3 & - & - & - \\
\hline
\end{tabular}

Keterangan:

SSS : Sangat Suka Sekali

SS : Sangat Suka

S : Suka

TS : Tidak Suka

Hasil uji kesukaan sediaan lip gloss menggunakan ekstrak ubi jalar ungu dilakukan untuk mengetahui tingkat kesukaan panelis terhadap warna, bau, dan daya oles, jumlah responden 3 orang dan yang memilih sangat suka sekali yaitu formula 2.

e. Uji Iritasi

Data hasil uji iritasi dapat diliat pada Tabel berikut ini:

Tabel 7. Hasil Uji Iritasi

\begin{tabular}{cccc}
\hline Hari & \multicolumn{3}{c}{ Hasil Pengamatan } \\
& 0 & 1 & 2 \\
\hline 1 & 3 & - & - \\
2 & 3 & - & - \\
3 & 3 & - & - \\
\hline
\end{tabular}

Hasil uji iritasi yang dilakukan oleh 3 orang panelis yaitu menghasilkan nilai 0, yang artinya tidak menghasilkan reaksi pada kulit yaitu tidak menimbulkan gatal-gatal pada kulit bibir dan tidak menimbulkan tanda kemerahan karena iritasi. Pengujian ini telah membuktikan bahwa lip gloss alami ekstrak ubi jalar ungu memang aman digunakan.

\section{KESIMPULAN}

Berdasarkan hasil penelitian yang telah dilakukan terhadap formulasi sediaan lip gloss dari esktrak etanol ubi jalar ungu (Ipomoea batatas L) dapat disimpulkan bahwa ekstrak ubi jalar ungu (Ipomoea batatas L) dapat diformulasikan dalam bentuk sediaan lip gloss. Sediaan lip gloss yang menghasilkan warna yang baik terdapat pada uji F2 yang konsentrasi $35 \%$. Evaluasi sediaan lip gloss homogen, $\mathrm{pH}$, daya oles, kesukaan dan iritasi memenuhi persyaratan lip gloss yang baik.

\section{DAFTAR PUSTAKA}

Ernawati, Dian, Uswatun, Nurul Hidayah (2017). Optimasi Formulasi Sediaan Lipstik Mengandung Ekstrak Etanol Ubi Jalar Ungu (Ipomoea batatas L). Prosiding Rapat Kerja Fakultas Ilmu Kesehatan.

Risnawati. dkk (2012). Formulasi Lipstik Menggunakan Ekstrak Biji Coklat (Theobroma cacao L.) Sebagai Pewarna. Fakultas Farmasi Universitas Sumatra Utara, Medan

Hardayani, Fransiska Vita, dkk (2015). Formulasi Sediaan Lipstik Menggunakan Ekstrak Buah Naga Super Merah (Hylocereus costaricensis) sebagai Zat warna alami. Universitas Pakuan. Bogor 


\section{Journal of Pharmaceutical and Health Research}

Vol 2, No 3, Oktober 2021, pp. 82-86

ISSN 2721-0715 (media online)

DOI 10.47065/jharma.v2i3.1302

Yuniarty, Tuty (2016). Pemanfaatan Sari ubi Jalar Ungu (Ipomoea batatas L) sebagai zat pewarna pada pewarnaan staphylococcus aureus, poltekes kemenkes, Kendari.

Yogaswara (2015). Optimasi Formula Sediaan Lipstik ekstrak Etanolit Umbi Jalar Ungu (Ipomoea batatas L) dengan Kombinasi Basis Carnauba Wax dan paraffin wax menggunakan Metode SLD (Simplek Lattice Design). Universitas Gajah Mada, Yogyakarta. 